\title{
Assessment of an electrical coolant pump on a heavy-duty diesel engine
}

\author{
Markus Kiesenhofer ${ }^{1}$ (1)
}

Received: 22 September 2020 / Accepted: 4 February 2021 / Published online: 19 February 2021

(c) The Author(s) $2021 \quad$ OPEN

\begin{abstract}
Hybridization of the drive train in commercial vehicles is a key solution toward meeting the strict future requirements to reduce carbon dioxide emissions within the European Union. In order to decrease fleet consumption a large number of different hybrid systems are already available in series in the passenger car sector. Due to the cheap and powerful 48 volt hybrid components and the lower hazard potential compared to high voltage, future commercial vehicles could also benefit from the $48 \mathrm{~V}$ technology and contribute to lower fleet fuel consumption. Therefore, a complete $48 \mathrm{~V}$ mild hybrid system was built on the diesel engine test bench as part of a research project. This paper highlights the utilization of a powerful $48 \mathrm{~V}$-motor to propel the coolant pump on a diesel engine of the $13-\mathrm{L}$ commercial vehicle class. Three different drive variants of the coolant pump were implemented and measured on the diesel engine test bench. MATLAB ${ }^{\circledast} /$ Simulink ${ }^{\oplus}$-simulations were conducted to assess the possible fuel savings in three different driving cycles. This paper provides a summary and interpretation of the measurement and simulation results. The simulation studies predict a decrease of fuel consumption of up to $0.94 \%$. Furthermore, the additional advantages of electrified coolant pumps based on $48 \mathrm{~V}$ are discussed.
\end{abstract}

Keywords Electrical coolant pump $\cdot$ Heavy-duty diesel engine $\cdot H D D$ engine $\cdot 48 \mathrm{~V} \cdot 48 \mathrm{~V}$ mild hybrid system $\cdot$ Internal combustion engine $\cdot$ Electrified auxiliaries $\cdot$ Engine test bench $\cdot$ Engine dynamometer

\begin{tabular}{|c|c|c|c|}
\hline \multicolumn{2}{|l|}{ Abbreviations } & $8 \mathrm{PK}$ & $\begin{array}{l}\text { Belt profile "8PK" } \\
\text { Amnere }\end{array}$ \\
\hline$\%$ & Percent & A & Ampere \\
\hline$\rho$ & Average density $\left[\mathrm{kg} / \mathrm{m}^{3}\right]$ & bar & Unit of pressure $\left(1 \mathrm{bar}=10^{5} \mathrm{~N} / \mathrm{m}^{2}\right)$ \\
\hline$\eta$ & Efficiency $[-]$ & CAN & Controller area network (standard- \\
\hline$\Omega$ & Ohm (electrical resistance) & & ized bus system) \\
\hline$\Delta p$ & Pressure difference $\left[\mathrm{N} / \mathrm{m}^{2}\right]$ & $\mathrm{CO}_{2}$ & Carbon dioxide \\
\hline$\Delta p_{\text {total }}$ & $\begin{array}{l}\text { Total pressure difference }\left[\mathrm{N} / \mathrm{m}^{2}\right] \\
\text { (translated) }\end{array}$ & D2676 & $\begin{array}{l}\text { Type designation of MAN diesel } \\
\text { engine }\end{array}$ \\
\hline$\dot{V}$ & Volume flow $\left[\mathrm{m}^{3} / \mathrm{s}\right]$ & DC-to-DC converter & Voltage converter (in this case: \\
\hline$€ / \mathrm{gCO}_{2} / \mathrm{tkm}$ & Euro per gram $\mathrm{CO}_{2}$ per tonne & & $48 \mathrm{~V} / 24 \mathrm{~V})$ \\
\hline & kilometer & ECU & Engine control unit \\
\hline$\circ$ & Degree (angle) & EGR & Exhaust gas recirculation \\
\hline${ }^{\circ} \mathrm{C}$ & Degree celsius & EM & Electric motor \\
\hline $24 \mathrm{~V}$ & 24 Volts & EU & European Union \\
\hline
\end{tabular}

Markus Kiesenhofer, markus.kiesenhofer@man.eu| ${ }^{1}$ MAN Truck \& Bus Österreich GesmbH, Engineering Powertrain - Organization \& Research, Steyr, Austria. 


\begin{tabular}{|c|c|}
\hline EURO VId & $\begin{array}{l}\text { European emission standards, Tier } \\
\text { "Euro 6d" }\end{array}$ \\
\hline f.m.v. & From measured value \\
\hline g & Gravitational acceleration $\left[\mathrm{m} / \mathrm{s}^{2}\right]$ \\
\hline $\mathrm{g} / \mathrm{cm}^{3}$ & Gram per cubic centimeter \\
\hline GesmbH & General corporate form in Austria \\
\hline $\mathrm{H}$ & Pressure head $[\mathrm{m}]$ \\
\hline hp & Horsepower ( $1 \mathrm{hp} \approx 735.5 \mathrm{~W})$ \\
\hline$i$ & Transmission ratio \\
\hline ICE & Internal combustion engine \\
\hline $\mathrm{kg}$ & Kilogram \\
\hline $\mathrm{kg} / \mathrm{h}$ & Kilogram per hour \\
\hline $\mathrm{kg} / \mathrm{m}^{3}$ & Kilogram per cubic meter \\
\hline km & Kilometer \\
\hline $\mathrm{km} / \mathrm{h}$ & Kilometer per hour \\
\hline kW & Kilowatt \\
\hline $\mathrm{L} / \mathrm{min}$ & Liter per minute \\
\hline LIN & $\begin{array}{l}\text { Local interconnect network } \\
\text { (standardized bus system) }\end{array}$ \\
\hline m & Meter \\
\hline$m^{2}$ & Square meter \\
\hline$m^{3}$ & Cubic meter \\
\hline MAN & Maschinenfabrik \\
\hline$M_{d}$ & $\begin{array}{l}\text { Augsburg-Nurnberg } \\
\text { Torque [Nm] }\end{array}$ \\
\hline $\min$ & Minute \\
\hline $\mathrm{mm}$ & Millimeter \\
\hline $\mathrm{n}$ & Speed $\left[s^{-1}\right]$ \\
\hline $\mathrm{N}_{2}$ & $\begin{array}{l}\text { Vehicle of category } \mathrm{N}_{2} \text { with } \\
\text { a maximum overall mass of } \\
3.5-12 \text { tonnes }\end{array}$ \\
\hline $\mathrm{N}_{3}$ & $\begin{array}{l}\text { Vehicle of category } \mathrm{N}_{3} \text { with a } \\
\text { maximum overall mass greater } \\
\text { than } 12 \text { tonnes }\end{array}$ \\
\hline $\mathrm{N}$ & Newton \\
\hline $\mathrm{Nm}$ & Newton meter \\
\hline Ns & Newton seconds \\
\hline$P_{d r}$ & Drive power [W] (translated) \\
\hline$P_{\text {eff }}$ & Effective power [W] (translated) \\
\hline PT100 & $\begin{array}{l}\text { Platinum resistance sensor with } \\
100 \Omega \text { electrical resistance at } 0{ }^{\circ} \mathrm{C}\end{array}$ \\
\hline PTM & $\begin{array}{l}\text { Power train manager (MAN } \\
\text { system) }\end{array}$ \\
\hline PWM & Pulse-width modulation \\
\hline rad & Radian $\left(1 \mathrm{rad} \approx 57.29^{\circ}\right)$ \\
\hline rpm & Revolutions per minute \\
\hline s & Second \\
\hline SCR & $\begin{array}{l}\text { Selective catalytic reduction (after } \\
\text { treatment system for exhaust } \\
\text { gases) }\end{array}$ \\
\hline SOC & $\begin{array}{l}\text { State of charge (level of charge of } \\
\text { the lithium-ion battery) }\end{array}$ \\
\hline $\mathrm{T}$ & Temperature \\
\hline
\end{tabular}

$\begin{array}{ll}\mathrm{T}_{\text {Meas }} & \text { Measured temperature } \\ \text { Tonne } & 1 \text { Tonne }=1000 \mathrm{~kg} \\ \mathrm{~V} & \text { Volt } \\ \mathrm{W} & \text { Watt }\end{array}$

\section{Introduction}

The European Union has set itself the goal of reducing the emission of carbon dioxide for the registration of heavyduty commercial vehicles in categories $\mathrm{N}_{2}$ and $\mathrm{N}_{3}$ with precisely defined properties by $15 \%$ from 2025 and by $30 \%$ from 2030 onwards. For this purpose, the fleet average of the affected vehicles within the European Union and a reference value for $\mathrm{CO}_{2}$ emissions was determined from July 1,2019 to June 30,2020 . This reference value across the entire fleet average is the basis for the reduction of $\mathrm{CO}_{2}$ emissions and therefore also for the necessary fuel consumption savings in the fleet average of 15\% by 2025 and $30 \%$ by 2030 . Precise regulations were published by the European Union, which can be found in [1]. The approach was justified by the fact that a total of $6 \%$ of $\mathrm{CO}_{2}$ emissions and approximately $25 \%$ of carbon dioxide emissions from road traffic within the European Union are caused by heavy-duty commercial vehicles (trucks and buses). Up to summer 2019 there were no restrictions on $\mathrm{CO}_{2}$ emissions for this vehicle category. The reason for this regulation is the mandatory compliance with the Paris Agreement and therefore $\mathrm{CO}_{2}$ emissions must be reduced in all areas [1]. For exceeding $\mathrm{CO}_{2}$ emissions, the European Union specified severe penalties of $4250 € / \mathrm{gCO}_{2} / \mathrm{tkm}$ from 2025 and $6800 € / \mathrm{gCO}_{2} / \mathrm{tkm}$ from 2030 [1], which would hit the commercial vehicle manufacturers massively. Manufacturers of commercial vehicles will try to avoid these penalties and therefore an increased effort for research and development in the area of alternative drivetrains will be necessary in the next few years.

The diesel engines of modern commercial vehicles (EURO VId standard) are very efficient and achieve efficiencies greater than $45 \%$ at their best operating point. For heavy-duty commercial vehicles in the categories $\mathrm{N}_{2}$ and $\mathrm{N}_{3}$ innovative approaches will be required in order to be able to achieve further savings in fuel consumption to the extent mentioned above.

The hybridization of the powertrain on a $48 \mathrm{~V}$ basis is one of the possible approaches to contribute to a decreasing fleet consumption. In hybridization, excess kinetic or potential energy can be converted into electrical energy and temporarily stored in an energy storage device (e.g. lithium-ion battery or Ultracap storage). With this energy, e.g. the electrified auxiliary units of the diesel engine can be supplied. Furthermore, a hybrid system can be utilized to support the internal combustion engine with an electric 
motor (boosting) in order to reduce the amount of fuel injected and therefore the fuel consumption. The recuperated energy can also supply the $24 \mathrm{~V}$ electrical system. All these measures serve to increase the overall efficiency of the powertrain and contribute to reduce fuel consumption in real driving operation. This is one of the feasible approaches to avoid the penalties (charges) threatened in [1] in case the average $\mathrm{CO}_{2}$ emissions are exceeded.

In the past few years several papers and book chapters about electrical coolant pumps for passenger cars have been published, e.g. [2-6]. Regarding the subject of electrical coolant pumps for long-haul trucks less papers can be found in the literature, e.g. $[7,8]$. The specific aim of this paper is to utilize a series $48 \mathrm{~V}$-motor to propel the coolant pump of a long-haul truck and determine the fuel savings in the entire engine map and in three different driving cycles, respectively.

In the course of this project a state-of-the-art heavyduty diesel engine with $12.4 \mathrm{~L}$ displacement and a rated power of $375 \mathrm{~kW}$ was investigated on the engine test bench. This work focuses on the electrification of the coolant pump by means of a powerful $48 \mathrm{~V}$-motor, which is part of a P0-hybrid system. Therefore, three different drive types were realized and measurements were conducted on the engine test bench. The utilized 48V-motor and the three different drive types are described in Sect. 5 . In addition, the setup on the engine test bench and the measurement technology are characterized.

In summary, the measurement results and the potential for savings in the entire engine map are presented and discussed. An overview of additional advantages of electrified coolant pumps is given just before the paper is finalized with Sect. 10.

\section{Coolant pump on a heavy-duty diesel engine}

The effective power of the coolant pump can be calculated with the formula 1 [9]:

$P_{\text {eff }}=\Delta p_{\text {total }} \cdot \dot{V}=H \cdot \rho \cdot g \cdot \dot{V}$

According to formula 1 the effective power $P_{\text {eff }}$ of the coolant pump depends on the pressure difference $\Delta p_{\text {total }}$ and the volume flow $\mathrm{V}$.

Due to the efficiency loss of the coolant pump, a higher drive power is required [9]:

$P_{d r}=\frac{P_{\text {eff }}}{\eta}$

According to [9] the pump efficiency depends on coolant density, coolant temperature, impeller geometry, impeller speed and pressure difference between the inlet and outlet.

As stated in [9] and based on the similarity theory for fluid flow machines the following relationships apply to coolant pumps:

$\frac{\mathrm{n}_{1}}{\mathrm{n}_{2}}=\frac{\dot{\mathrm{V}}_{1}}{\dot{\mathrm{V}}_{2}}$

$\frac{\mathrm{n}_{1}^{2}}{\mathrm{n}_{2}^{2}}=\frac{\Delta \mathrm{p}_{1}}{\Delta \mathrm{p}_{2}}=\frac{M_{d 1}}{M_{d 2}}$

$\frac{\mathrm{n}_{1}^{3}}{\mathrm{n}_{2}^{3}}=\frac{\mathrm{P}_{\text {eff } 1}}{\mathrm{P}_{\text {eff2 }}}$

Formula 3 shows that there is a linear relationship between pump speed and volume flow. If the pump speed is doubled the volume flow is doubled, too. According to Formula 4 the pump torque requirement and the pump pressure difference increase quadratically with the speed. Therefore, the required pump torque and the pressure difference quadruple in case the pump speed is doubled. The effective power of the coolant pump increases with the third power of the pump speed, as presented in Eq. 5 . The required drive power of the coolant pump increases similarly with the effective power, but the ratio depends on the efficiency curve of the pump impeller.

According to formulas 3, 4 and 5 an increase of volume flow by e.g. $10 \%$ requires $21 \%$ more pump torque and $33.1 \%$ more effective power of the coolant pump. To safe mechanical or electrical energy to propel the coolant pump, the volume flow should be as low as possible. For this purpose a lot of measurements were conducted on the engine test bench at MAN Nuremberg, which are not further discussed in this paper.

In commercial vehicles it is possible that a very large part of the engine power is needed at low driving speed or even when the vehicle is operated stationary. The entire cooling system of the commercial vehicle must be designed for this worst case scenario, taking into account all components, which must be heated (cabin heating) or cooled (gear box, air compressor, etc.) by utilization of the coolant. Therefore, large heat transfer surface of radiators, installed in the cooling package and powerful cooling fans are necessary to provide the required cooling performance. In cutting-edge commercial vehicles, the radiator fan is coupled to the diesel engine via an electrically adjustable viscous clutch so that a demand-oriented radiator fan speed can be set. In this case, the required drive power for the radiator fan is provided by the diesel engine and this reduces the available power to propel the vehicle. 
The mechanically driven coolant pump of the investigated diesel engine of the 13-L-class needs up to $7 \mathrm{~kW}$ mechanical power. These high power values are only necessary in retarder operation, but not in fired diesel engine operation [10]. Reduction of fuel consumption by introducing an adjustable pump is realized by the pump and fan regulation system. The so-called cascade control system that connects the components according to lower energy consumption (pump first, then fan depending on vehicle speed and external parameters) is implemented in the ECU/PTM control systems of the diesel engine [11].

\section{State of the art}

In a commercial vehicle diesel engine about $24 \%$ of the fuel energy must be dissipated via the cooling system [12]. A water-ethylene glycol mixture is usually utilized as a coolant, because this medium offers a high specific heat capacity and a low freezing point (approx. $-50^{\circ} \mathrm{C}$ ). Special additives are added to the water-ethylene glycol mixture to protect the engine against corrosion and cavitation [12]. The density of this mixture is reduced from $1073 \mathrm{~kg} / \mathrm{m}^{3}$ at $30{ }^{\circ} \mathrm{C}$ to $1036 \mathrm{~kg} / \mathrm{m}^{3}$ at $90^{\circ} \mathrm{C}[13]$. Hence, the temperaturerelated reduction in density is approximately $-3.5 \%$. The dynamic viscosity of this coolant is $2.607 \mathrm{Ns} / \mathrm{m}^{2}$ at $30^{\circ} \mathrm{C}$ and $0.737 \mathrm{Ns} / \mathrm{m}^{2}$ at $90^{\circ} \mathrm{C}$ [13]. The reduction in dynamic viscosity as a result of the temperature increase from $30^{\circ} \mathrm{C}$ to $90^{\circ} \mathrm{C}$ is approx. $-71.7 \%$.

In order to ensure that the heat is removed, a coolant pump is needed. In the optimum case, the coolant pump provides exactly the required coolant volume flow. In cutting-edge commercial vehicles, the heat is dissipated to the environment by a coolant-air heat exchanger located at the vehicle front. This coolant-air heat exchanger is the heat sink for the cooling system.

Today's mechanical coolant pumps are usually coupled to the combustion engine via a belt drive with a constant or adjustable (utilization of a viscous clutch) transmission ratio. The transmission ratio of the coolant pump to the diesel engine is designed for boiling-critical points in the cooling circuit [12]. The rigid coupling has the disadvantage that high coolant pump speeds are set at high diesel engine speeds. This causes high coolant volume flows and therefore high power requirements of the coolant pump. A rigid coupling leads to correspondingly high coolant volume flows, even if these may not be needed at all, because the diesel engine is operated at high speed but with low load. However, the large coolant volume flows do not provide any advantage for engine cooling at these engine operating points. The large power consumption of the coolant pump decreases the available propulsion power and increases the fuel consumption in these operating phases.

An improvement of the situation can be achieved by using a viscous clutch on the coolant pump. In this case, the torque is transmitted from the pulley to the impeller of the coolant pump via a silicone oil, which is located in the working chamber of the viscous clutch. Due to variation of the silicone oils quantity the torque transmission, the power requirement and the coolant pump speed can be controlled. The amount of silicone oil in the working chamber can be varied by means of a solenoid valve, which is controlled by pulse-width modulation (PWM). To ensure a failsafe operation in case the solenoid valve fails or a cable breaks, all silicone oil should remain in the working chamber. In this case the fuel saving potential of the controlled coolant pump cannot be realized, but a malfunction of the combustion engine can be avoided.

According to [12], the use of a viscous clutch for demand-oriented control of the coolant flow rate can achieve fuel savings of up to $1 \%$ in long-haul transport applications. Due to the controllability of the viscous clutch, the required mechanical power of the coolant pump can be reduced by $80 \%$ [10].

In the case of a demand-oriented coolant pump for commercial vehicles on the market, the power flow follows this path: belt-pulley-clutch housing-silicone oil (shear force)-viscous wheel-bearing shaft-impeller [14]

In order to transmit torque by means of silicone oil (shear forces), slip must exist between the pulley speed and the impeller speed. The slip mentioned in [14] is up to $5 \%$. To protect the silicone oil from overheating, the oil level in the working chamber must not fall below a defined minimum level. As a result, the impeller speed of the controlled coolant pump with viscous coupling presented in [14] cannot be less than $25 \%$ of the pulley speed. For this reason, the impeller speed of this controlled coolant pump can only be varied within a range of $25-95 \%$ of the belt pulley speed. This shows, that even with a demand-controlled coolant pump with viscous clutch, not all impeller speed ranges and therefore volume flows can be realized without restrictions.

Both the rigid and the adjustable coolant pump with viscous clutch are coupled to the diesel engine with a belt drive. For this type of drive, losses occur due to the following effects [15]:

- pulsating tensile stress (internal loss)

- bending of the belt (internal loss)

- belt slip at the respective contact point with torque transmission (external loss)

- air resistance of the belt (external loss)

- bearing resistance at the deflection pulley and the tensioner pulley 
- air resistance of the deflection pulley and the tensioner pulley

In all internal combustion engines rotational irregularities occur, mainly caused by the high cylinder pressure gradients in the working stroke. These rotational irregularities subsequently lead to slip at the respective contact points of the belt drive. This type of loss is more severe at low speed and high load of the internal combustion engine. For the 12.4-L diesel engine, which was examined in this paper, the total loss of the belt drive is about 300-900 W [16].

\section{Electrification of the coolant pump}

In case a controlled coolant pump with viscous clutch is utilized, a more demand-oriented coolant volume flow can be realized in comparison to a rigid coupled coolant pump. As already mentioned in the previous section, physical mechanisms (shear forces, maximum temperature of the silicone oil, losses in the belt drive) limit the achievable impeller speed and coolant volume flows.

In order to further optimize the feasible coolant volume flows, the utilization of an electrical coolant pump is recommended. By using a suitable electric motor to drive the coolant pump, coolant volume flows from $0 \mathrm{~L}$ per minute up to the maximum required coolant volume flow can be provided. Therefore, the electrified coolant pump offers the highest degrees of freedom in the representation of the volume flows in the cooling system.

Model calculations are conducted in the engine control unit (ECU) to determine the required coolant volume flow depending on the following influencing factors:

- engine speed

- load point

- coolant temperature

- oil temperature

- ambient temperature

- radiator fan speed

- required minimum coolant flow rate of the auxiliaries (e.g. air compressor)

- required minimum coolant flow rate of the heat exchanger for the cabin heater

The output value of this calculation model is the required impeller speed, which can be adjusted within fractions of a second due to the good dynamics and controllability of an electric motor.

\section{Perception of the investigated concepts}

In this paper the replacement of the belt-driven coolant pump with viscous clutch by an electrically driven coolant pump is highlighted. The electric motor utilized to drive the coolant pump is part of a $48 \mathrm{~V}$ mild hybrid system consisting of the following components:

- Electrical coolant pump

- Electrical air-conditioning compressor

- Motor-generator-unit for recuperation and boosting

- Lithium-ion battery

- DC-to-DC converter (48V/24V)

- Rapid prototyping hardware

One of the possible distinctions between the different hybrid topologies is the location of the electric motor in the powertrain. According to [17], the hybrid propulsion systems are divided into the following topologies:

- P0-hybrid: Electric motor on the belt drive (beltstarter-generator)

- P1-hybrid: Electric motor on the crankshaft (crankshaft-starter-generator)

- P2-hybrid: Electric motor between clutch and gearbox input

- P3-hybrid: Electric motor at gearbox output

- P4-hybrid: Electric motor on separate axle

- P5-hybrid: wheel hub motor

Figure 1 presents the different hybrid topologies on a symbolic powertrain.

The amount of energy gained from regenerative braking (recuperation) has to be temporarily stored in the vehicle to reuse it later for boosting, for driving the electrified auxiliary units and for supplying the electrical system. There are also different approaches to energy storage (electrochemical storage, capacitors, hydraulic storage, pneumatic storage, flywheel energy storage, ...), which depend on the application scenario. Some properties for electrical energy storage systems are listed below:

- voltage level

- amount of stored electrical energy

- charging and discharging power

- required lifetime

- internal resistance

- temperature sensitivity

- weight

- assembly space

- costs 
Fig. 1 Different hybrid topologies (symbolic powertrain)

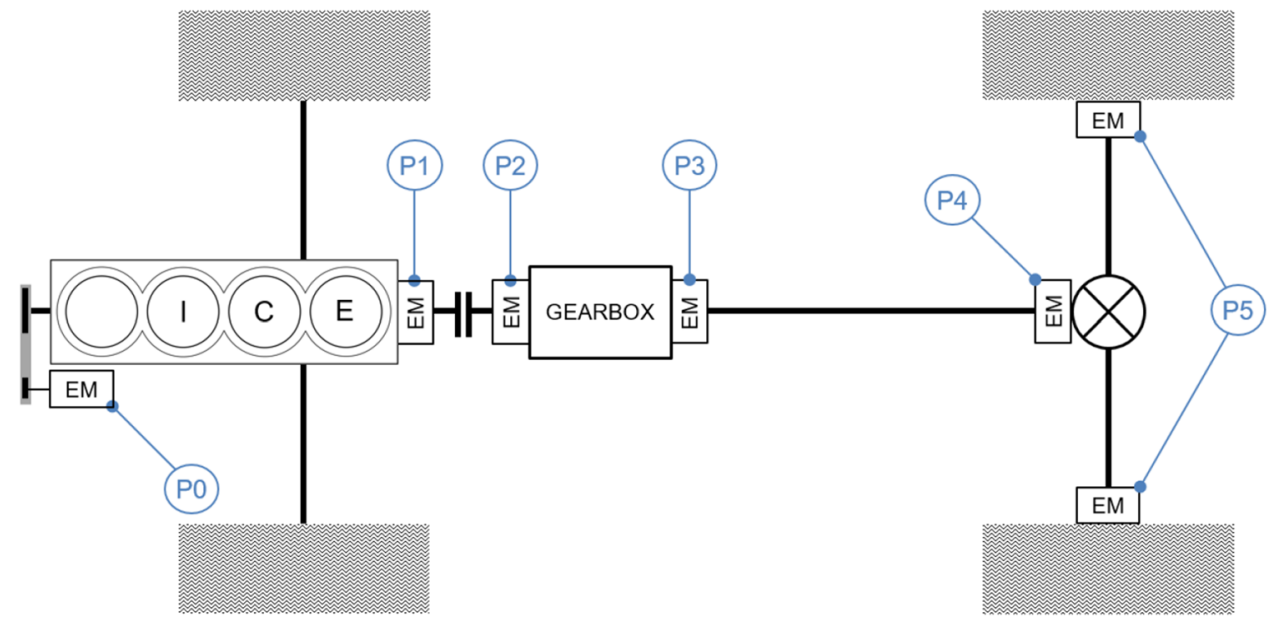

Which energy storage device should be used depends on a large number of factors and must be determined specifically for each vehicle type and the area of application (typical load quantity and route profile).

In this paper only the electrical coolant pump is presented more closely. All other components of the $48 \mathrm{~V}$ mild hybrid system ( $\mathrm{PO}$-hybrid with lithium-ion battery) are not discussed in detail in this article.

As mentioned above the required coolant volume flow is determined by means of a MAN-internal calculation model, which runs on the ECU. The calculated impeller speed represents the ideal coolant volume flow for the diesel engine and the auxiliary units. The results of this calculation model are utilized as a set point for the impeller speed of the series coolant pump with viscous clutch and for all three different electrically driven variants presented in this paper.

\subsection{Brief presentation of the electric motor}

To ensure, that both the entire speed and power range of the coolant pump are covered, the electric motor must be selected carefully. This is the only way to guarantee, that all volume flows determined by the calculation model can be provided.

For the investigations explained in this paper, a $48 \mathrm{~V}$ engine was used, which has been in series production since 2017. In Table 1 some technical data of this $48 \mathrm{~V}$ motor are listed:

This $48 \mathrm{~V}$ motor was chosen because its performance and maximum continuous torque make it very suitable for driving the coolant pump. Another advantage is the series production in the passenger car sector, which is why this $48 \mathrm{~V}$ motor is quickly available at low cost.
Table 1 Properties of the $48 \mathrm{~V}$ engine

\begin{tabular}{|c|c|}
\hline Properties & Value \\
\hline Maximum motor power (5 s) & $6.3 \mathrm{~kW}^{\mathrm{a}}$ \\
\hline Maximum continuous motor power @ 2000 rpm & $5 \mathrm{~kW}^{\mathrm{b}}$ \\
\hline Maximum continuous motor power @ 4000 rpm & $5.4 \mathrm{~kW}^{\mathrm{b}}$ \\
\hline Maximum continuous motor power @ 6000 rpm & $5.4 \mathrm{~kW}^{\mathrm{b}}$ \\
\hline Maximum torque $(\mathrm{n}<50 \mathrm{rpm})$ for $0.5 \mathrm{~s}$ & $62.3 \mathrm{Nm}^{\mathrm{a}}$ \\
\hline Weight & approx. $13 \mathrm{~kg}^{\mathrm{a}}$ \\
\hline Length of housing & approx. $190 \mathrm{~mm}^{\mathrm{a}}$ \\
\hline Diameter of housing & approx. $200 \mathrm{~mm}^{\mathrm{a}}$ \\
\hline Maximum coolant flow rate & 13.15 L per $\min ^{\mathrm{a}}$ \\
\hline Maximum coolant temperature & $105^{\circ} \mathrm{C}^{\mathrm{a}}$ \\
\hline
\end{tabular}

The name of the manufacturer of this $48 \mathrm{~V}$ motor is not mentioned in this paper

${ }^{\text {a }}$ Manufacturer information

${ }^{\mathrm{b}}$ Measurement result from MAN Steyr

\subsection{Direct drive of the coolant pump}

The first implemented variant was a direct drive in which the $48 \mathrm{~V}$ motor is directly connected to the shaft of the coolant pump. An elastic claw coupling was used as a connection element. With this connection element, angular errors of up to $1.2^{\circ}$ and maximum axial displacements of $-0.5 \mathrm{~mm}$ or $+1.2 \mathrm{~mm}$ can be compensated [18]. This means that the flexible claw coupling can absorb the usual assembly inaccuracies. Figure 2 shows the setup of the direct drive, the $48 \mathrm{~V}$ motor with coolant lines (only the coolant drain is visible), the $48 \mathrm{~V}$ wires and the CAN wires (control signals) are distinguishable.

In this case the transmission ratio $i=1$ and therefore the speed of the $48 \mathrm{~V}$ engine is equal to the coolant pump speed. The impeller is mounted on the shaft by means of a press fit and the torque is transmitted backlash-free 


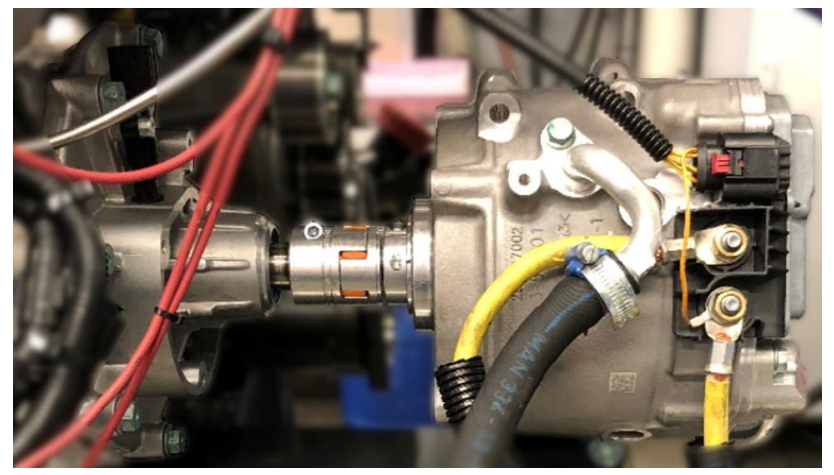

Fig. 2 Direct drive of the coolant pump

by friction. The measurement results of this drive variant are presented in Sect. 8.

\subsection{Drive of the series coolant pump with viscous clutch by means of a short belt drive}

The efficiency of the $48 \mathrm{~V}$ motor depends, among other influencing factors, on the speed and load. At a speed of $2000 \mathrm{rpm}$, the $48 \mathrm{~V}$ motor has an average efficiency of approx. $73 \%$ (average value over all measured torque values at $2000 \mathrm{rpm}$; electrical wire losses and inverter losses are included). At a speed of $4000 \mathrm{rpm}$ an average efficiency of approx. $77 \%$ (average value over all measured torque values at $4000 \mathrm{rpm}$ ) was calculated.

For measurements on the MAN D2676 diesel engine (which is presented in more detail in Sect. 6) a maximum coolant pump speed of approx. $2000 \mathrm{rpm}$ is required at a coolant temperature of $90^{\circ} \mathrm{C}$. This is necessary to provide the required coolant volume flow at all operation points, where fuel is injected.

In order to be able to operate the $48 \mathrm{~V}$ motor at a higher average efficiency, a second variant with a separate belt drive was tested. The advantage is that a transmission ratio of $\mathrm{i}>1$ can be realized. With this drive variant, the $48 \mathrm{~V}$ motor can be operated at higher average speeds and therefore at higher average efficiency levels. Nevertheless, the use of the belt drive results in further losses (see Sect. 3), which can partly compensate the efficiency increase of the $48 \mathrm{~V}$ motor. However, no general statement can be made about this assumption and that's the reason why this drive variant was also built and measured on the engine test bench.

Figure 3 shows the $48 \mathrm{~V}$ motor and the series coolant pump with viscous clutch. The torque transmission is realized via a $768 \mathrm{~mm}$ long multiple V-ripped belt (8PK).

The measurement results for this drive variant are presented and compared with all other variants in Sect. 8.

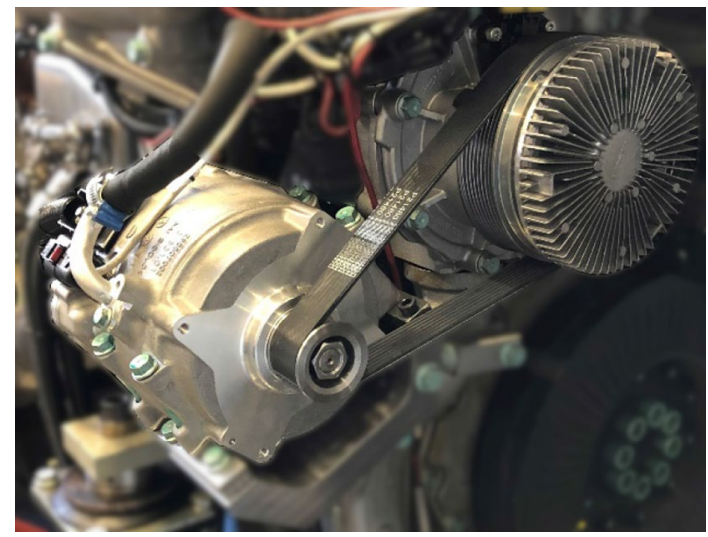

Fig. 3 Drive of the series coolant pump with viscous clutch by means of a belt

\subsection{Drive of the series coolant pump without viscous clutch by means of a short belt drive}

For the drive variant just presented, the unchanged series coolant pump with viscous clutch was utilized. In the series application it is the task of the viscous clutch to enable a controllability within certain limits (see Sect. 3). This reduces the power consumption of the coolant pump at most engine operating points with high engine speed but low load.

When driven by a $48 \mathrm{~V}$ motor, the controllability of the viscous clutch is not necessary, because the electric motor can be operated in all necessary speed ranges. The utilized $48 \mathrm{~V}$ motor is controlled via CAN communication. To adjust the speed of the $48 \mathrm{~V}$ engine in this case it's necessary to determine the torque value. The torque signal is a 16-bit signal and can therefore have 65,536 different values. Due to this high number of different values, the required coolant pump speed can be adjusted very precisely.

The average loss of the viscous clutch is about $200 \mathrm{~W}$, but can be more than $500 \mathrm{~W}$ in extreme situations [19]. These losses can be prevented by replacing the viscous clutch with a rigid drive. Figure 4 shows the $48 \mathrm{~V}$ motor and the series coolant pump without viscous clutch (rigid drive). The torque transmission is also carried out via a multiple V-ripped belt (8PK). Figure 5 shows a detailed view of the variant without viscous clutch. The design details will not be discussed here any further (Table 2).

\section{Setup on the engine test bench}

All measurements and tests were conducted on a dynamic engine test bench at MAN Truck \& Bus Österreich GesmbH in Steyr, Austria. As an internal combustion engine a 


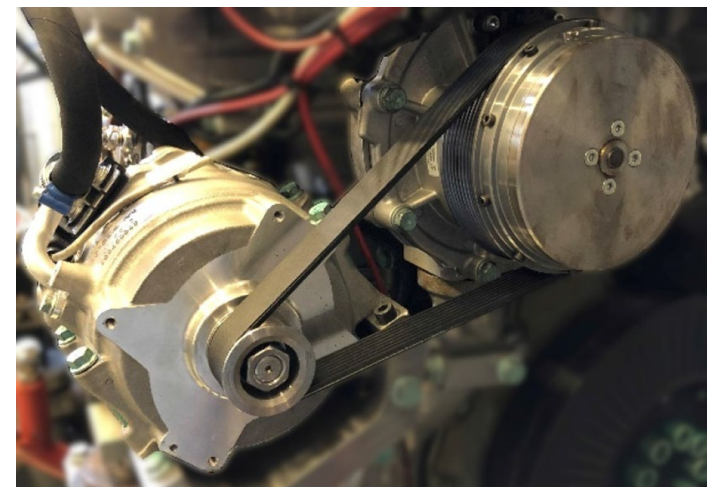

Fig. 4 Drive of the series coolant pump without viscous clutch by means of a belt

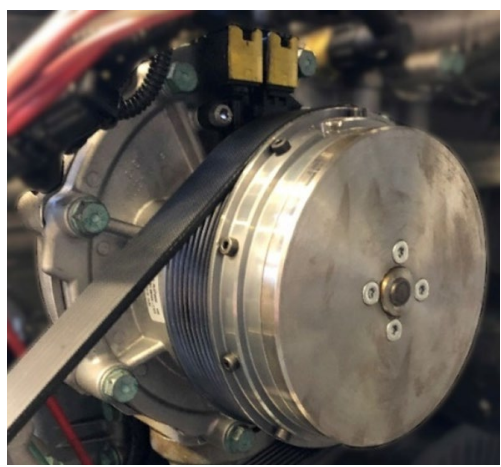

Fig. 5 Detailed view of the variant without viscous clutch

Table 2 Overview of the three different variants

\begin{tabular}{|c|c|c|c|}
\hline Variant & Short description & Belt drive & $\begin{array}{l}\text { Viscous } \\
\text { cou- } \\
\text { pling }\end{array}$ \\
\hline & $\begin{array}{l}\text { Overview of the three realized vari- } \\
\text { ants }\end{array}$ & & \\
\hline Variant 1 & Direct drive of the coolant pump & No & No \\
\hline Variant 2 & $\begin{array}{l}\text { Drive of the series coolant pump } \\
\text { with viscous clutch by means of a } \\
\text { short belt drive }\end{array}$ & Yes & Yes \\
\hline Variant 3 & $\begin{array}{l}\text { Drive of the series coolant pump } \\
\text { without viscous clutch by means } \\
\text { of a short belt drive }\end{array}$ & Yes & No \\
\hline
\end{tabular}

cutting-edge MAN D2676 diesel engine was chosen. The technical properties of this diesel engine are described in Table 3.

As mentioned in Sect. 5, three different variants to propel the coolant pump with the $48 \mathrm{~V}$ motor were realized. All investigations were conducted without the mechanical air conditioning compressor and without the $24 \mathrm{~V}$ generator. The multiple V-ripped belt, which
Table 3 Technical properties of the MAN D2676 [14]

\begin{tabular}{ll}
\hline Engine designation & MAN D2676 \\
Engine type & Diesel engine with 6 cylinders (inline) \\
Displacement & $12.4 \mathrm{~L}$ \\
Bore $x$ Stroke & $126 \mathrm{~mm} \times 166 \mathrm{~mm}$ \\
Rated power & $375 \mathrm{~kW} / 510 \mathrm{hp} @ 1800 \mathrm{rpm}$ \\
Maximum torque & $2600 \mathrm{Nm} @ 930 \mathrm{rpm}-1350 \mathrm{rpm}$ \\
\hline
\end{tabular}

is normally used to drive the auxiliaries units, was not necessary for these investigations and therefore was not mounted on the engine at all.

\section{Measurement technology on the engine test bench}

The diesel engine test bench is equipped with a lot of measurement technology. In this subsection the measurement technology relevant to this article is explained in more detail.

\subsection{Measurement of the coolant volume flow}

The coolant volume flow was determined by means of a Coriolis mass flow measuring system. The total coolant flow between the diesel engine and the heat exchanger was measured on the engine test bench. For this purpose the Coriolis mass flow measuring system "Promass 80F08" from the company "Endress + Hauser" was utilized (Table 4).

\subsection{Measurement of the coolant temperature}

The coolant temperature was measured at several points on the diesel engine, using PT100 temperature sensors. The basic principle of these temperature sensors is based on the fact that most materials increase or decrease their electrical resistance due to a change of temperature. This physical effect is used in resistance temperature measurement. The PT100 temperature sensor is standardized and uses the precious metal platinum as a metallic conductor. The electrical resistance is $100 \Omega$ at $0^{\circ} \mathrm{C}$. The advantage in comparison to thermocouples is the higher accuracy. The coolant temperature measurements on the engine test bench were conducted with PT100 temperature sensors of the "accuracy class A". The measurement deviations in this accuracy class are given as " $\pm\left(0.15^{\circ} \mathrm{C}+0.002 \cdot \mathrm{T}\right)$ ", whereby " $\mathrm{T}$ " has to be inserted in the formula in degree Celsius [21].

\section{SN Applied Sciences}


Table 4 Technical properties of the Coriolis mass flow measuring system [20]

\begin{tabular}{ll}
\hline Manufacturer & Endress + Hauser \\
Model designation & Promass $80 \mathrm{~F} 08$ \\
Measured values & mass flow, density, temperature \\
Measurement accuracy for mass flow & $\pm 0.15 \% \pm[($ zero stability: measured value $) \cdot 100] \%$ f.m.v \\
Measurement accuracy for volume flow & $\pm 0.20 \% \pm[($ zero stability: measured value $) \cdot 100] \%$ f.m.v \\
Measurement accuracy for density & $\pm 0.01 \mathrm{~g} / \mathrm{cm}^{3}$ \\
Measurement accuracy for temperature & $\pm 0.5^{\circ} \mathrm{C} \pm 0.005 \cdot \mathrm{T}_{\text {Meas }}\left({ }^{\circ} \mathrm{C}\right)$ \\
\hline
\end{tabular}

Table 5 Technical properties of the power supply [22]

\begin{tabular}{ll}
\hline Output voltage DC & $0-80 \mathrm{~V}$ \\
Output current DC & $0-340 \mathrm{~A}$ \\
Output power DC & $0-10,000 \mathrm{~W}$ \\
Rated voltage & $\mathrm{V}_{\text {rat }}=80 \mathrm{~V}$ \\
Rated current & $\mathrm{I}_{\text {rat }}=340 \mathrm{~A}$ \\
Rated power & $\mathrm{P}_{\text {rat }}=10,000 \mathrm{~W}$ \\
Accuracy of the voltage control $\left(\right.$ at $\left.23 \pm 5^{\circ} \mathrm{C}\right)$ & $<0.1 \%$ of $\mathrm{V}_{\text {rat }}$ \\
Accuracy of the current control $\left(\right.$ at $\left.23 \pm 5^{\circ} \mathrm{C}\right)$ & $<0.2 \%$ of $\mathrm{I}_{\text {rat }}$ \\
Accuracy of the power control $\left(\right.$ at $\left.23 \pm 5^{\circ} \mathrm{C}\right)$ & $<1 \%$ of $\mathrm{P}_{\text {rat }}$ \\
Weight & approx. $24 \mathrm{~kg}$ \\
\hline
\end{tabular}

\subsection{Measurement of current, voltage and electrical power of the $48 \mathrm{~V}$ motor}

During the measurements the power supply of the $48 \mathrm{~V}$ motor was ensured by a high-performance power supply unit. The power supply "PSI 9080-340 3U" from the German company "HEIDEN power GmbH" was utilized. The technical properties of this power supply are listed in Table 5.

This power supply offers the possibility of remote voltage sensing. For this purpose two additional wires are utilized for voltage measurement. The advantage is that the voltage value can be adjusted at the location of the remote sensing -in this case at the poles of the lithiumion battery. This method of voltage measurement with additional wires can compensate the voltage drop of the very long wires (approx. $8 \mathrm{~m}$ due to the structural conditions on the engine test bench). The voltage drop between the lithium-ion battery and the $48 \mathrm{~V}$ motor was not compensated with this method and therefore the voltage level at the $48 \mathrm{~V}$ motor is always lower than the voltage at the poles of the lithium-ion battery.

\subsection{Torque measurement at the $48 \mathrm{~V}$ motor}

To determine the maximum continuous torque and the maximum continuous motor power of the $48 \mathrm{~V}$ motor at different speeds, the torque measuring flange "digital torque transducer $\mathrm{T} 40 \mathrm{~B}$ " with a maximum permitted torque of $500 \mathrm{Nm}$ from the company "HBM Hottinger Baldwin Messtechnik $\mathrm{GmbH}^{\prime}$ "was utilized. The accuracy of this torque measuring flange is $\pm 0.05 \%$ of the final value [23]. The torque measurements were conducted on an independent measuring setup, which is not presented in the course of this article.

\subsection{Measurement of torque, speed and fuel consumption of the diesel engine}

Table 6 lists the different sensors that were used to measure the torque, speed and fuel consumption of the diesel engine. The respective measuring accuracies are also listed in Table 6.

\section{Results}

In this section, the results of the measurements on the engine test bench for all three realized drive variants of the electrified coolant pump are presented. A differentiation between the "short coolant circuit" and the "long coolant circuit" will be described in more detail in this section.

Table 6 Accuracy class of the different measurement systems on the diesel engine test bench

\begin{tabular}{lll}
\hline Sensor & Manufacturer & Accuracy \\
\hline $\begin{array}{l}\text { Torque transducer T40 } \\
\text { (final value 5000 Nm) [24] }\end{array}$ & HBM Hottinger Baldwin Messtechnik GmbH & $< \pm 0.05 \%$ f.m.v \\
$\begin{array}{l}\text { Speed sensor "ROD 436 (4096 I/U HTL 10-30 V)" } \\
{[25]}\end{array}$ & DR. JOHANNES HEIDENHAIN GmbH & $1 / 20$ of grating period \\
$\begin{array}{l}\text { Fuel consumption measurement } \\
\text { "PLU 116H-120" [26] }\end{array}$ & AVL Pierburg Instruments Flow Technology GmbH & $\pm 1 \%$ f.m.v \\
\hline
\end{tabular}


The "short coolant circuit" is active when the coolant temperature is below the opening temperature set in the thermostatic control valve (e.g. $87^{\circ} \mathrm{C}$ ) and it is therefore closed. In this case, the water-ethylene glycol mixture flows from the engine exit via a short-circuit line directly to the coolant pump, where it is sucked in again. If the thermostatic control opens because the coolant temperature rises above the limit, the "long coolant circuit" is active. After the engine exit, the coolant flows through a cooling module (heat exchanger), which is normally located at the front of the vehicle. This cooling module serves as a heat sink for the cooling system, in which heat is dissipated to the vehicle surroundings (to the ambient air) by convection, heat radiation and heat conduction (holder of the heat exchanger).

At the engine test bench a coolant-water heat exchanger is utilized. The heat energy dissipated is delivered to the company's own district heating network and used as process heat at the company site.

\subsection{Results for the "short coolant circuit"}

The electrical power requirement of the $48 \mathrm{~V}$ engine for the direct drive was determined as a function of the coolant pump speed and the results are shown in Fig. 6 . In order to quantify the differences between the two series of measurements, a polynomial of third order was created for each curve. In the speed range of $900 \mathrm{rpm}$ to $3200 \mathrm{rpm}$ the analysis shows that an average of about $6 \%$ less electrical power is needed to reach the same speed point of the coolant pump, if the coolant is hot.
The measured values show that the electrical power requirement to achieve the same pump speed is always higher with cold coolant than with warm coolant. This can be explained by the lower viscosity ("thin fluid") and the lower density of the coolant at higher temperature. Details on the temperature-dependent properties of the coolant were described in Sect. 3. The different torque requirements depending on the coolant temperature also have an impact on the efficiency of the $48 \mathrm{~V}$ engine and this in turn influences the need of electrical power.

The $48 \mathrm{~V}$ engine is cooled with the coolant of the diesel engine. The colder the coolant, the greater the performance of the $48 \mathrm{~V}$ engine. This fact can also be seen in Fig. 6 , because with cold coolant higher torque values and therefore higher pump speeds can be achieved than with hot coolant.

The volume flow cannot be measured in the short coolant circuit because the Coriolis flowmeter is located outside (between the shut-off valve and the heat exchanger) of this circuit. For this reason, only measurements with the variant "direct drive" were conducted in the short circuit, but not with the other two drive variants with belt drive.

The error bars shown in Figs. 6, 8, 9, and 10 represent the measurement error (worst case) of the power supply "PSI 9080-340 3U", which delivered the electrical energy for the 48V-motor to drive the coolant pump in all three different variants. The maximum measurement error of this power supply is $\pm 50 \mathrm{~W}$ (worst case), which is represented by the error bars.

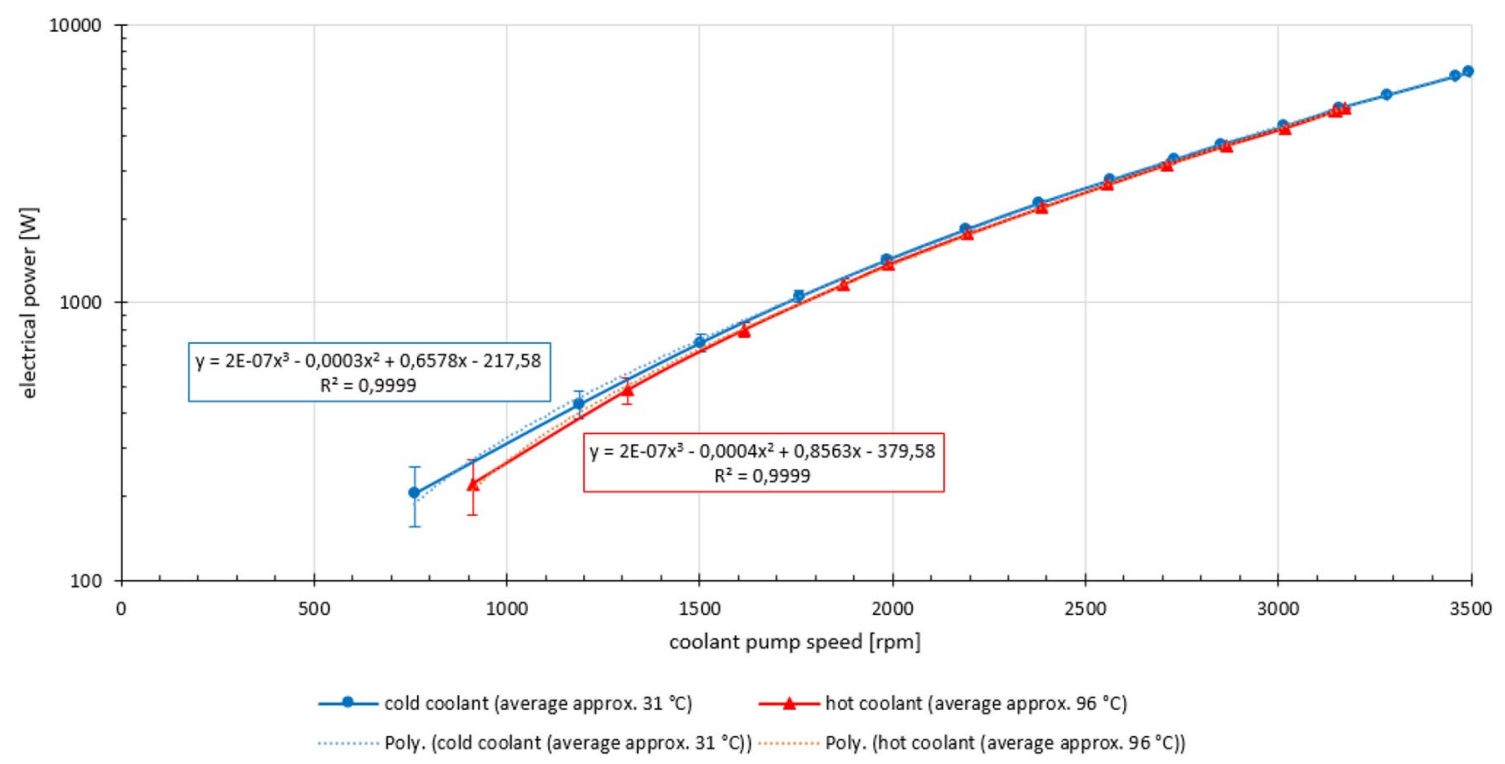

Fig. 6 Short coolant circuit: Electrical power as a function of speed for direct drive and different temperatures 


\subsection{Results for the "long coolant circuit"}

The relationship between volume flow and coolant pump speed for the long coolant circuit with direct drive is shown in Fig. 7. It was already mentioned in Sect. 2, that the relationship between volume flow and speed is linear. The measurement results are almost congruent with the first order polynomial, which was drawn into Fig. 7, to illustrate the linearity. A higher maximum speed can be achieved with cold coolant than with hot coolant (explanation below Fig. 6).
To determine the average deviation, a linear polynomial was calculated for each series of measurements and the mean difference was calculated. The evaluation of the polynomials between $700 \mathrm{rpm}$ and $2900 \mathrm{rpm}$ shows that when the diesel engine is warm, the volume flow at the same coolant pump speed is approximately $1.9 \%$ higher than with a cold diesel engine.

Figure 8 shows the relationship between electrical power of the $48 \mathrm{~V}$ motor and volume flow for the long coolant circuit. The average deviation between the two calculated polynomials was determined between $90 \mathrm{~L}$ per

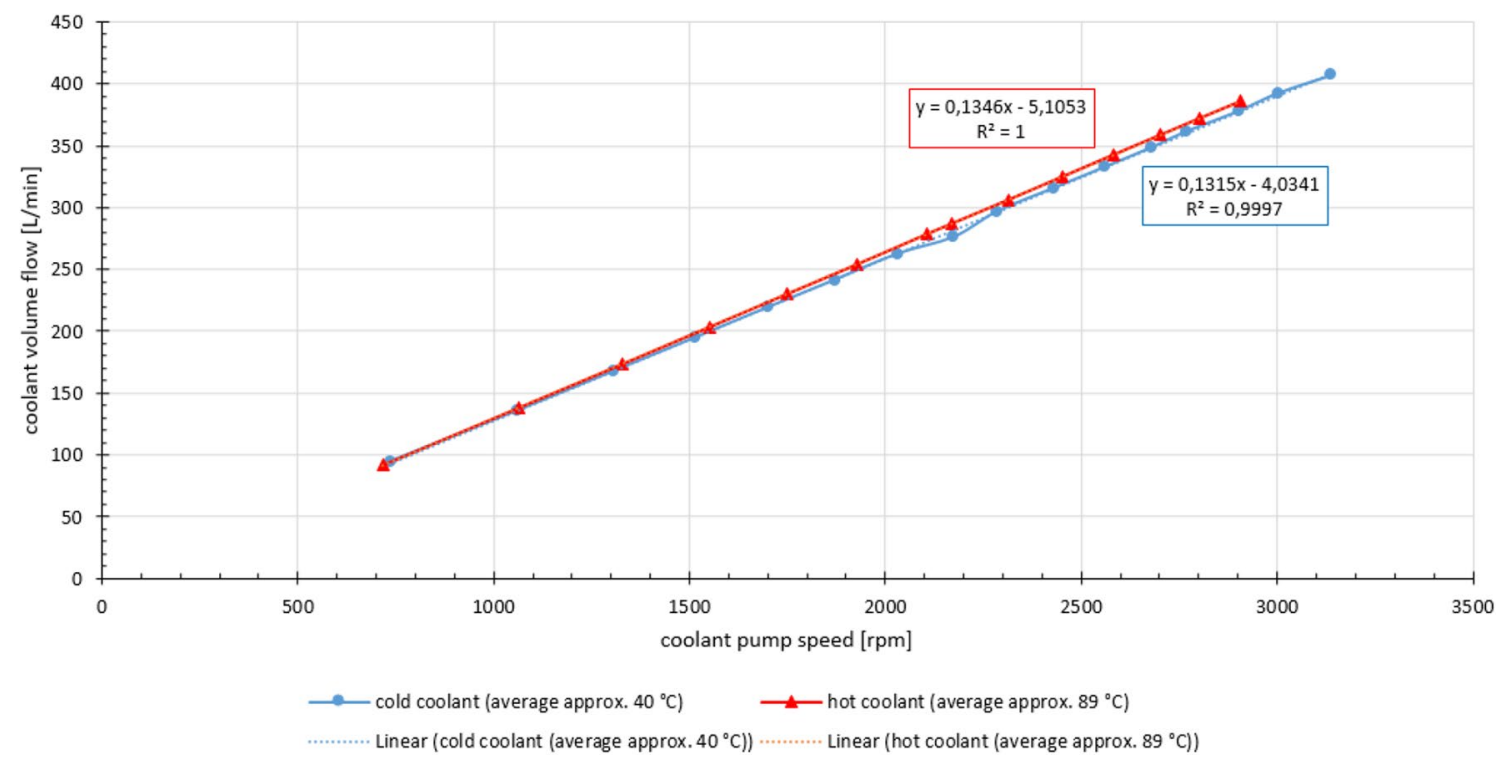

Fig. 7 Long coolant circuit: Volume flow as a function of speed for direct drive and different coolant temperatures

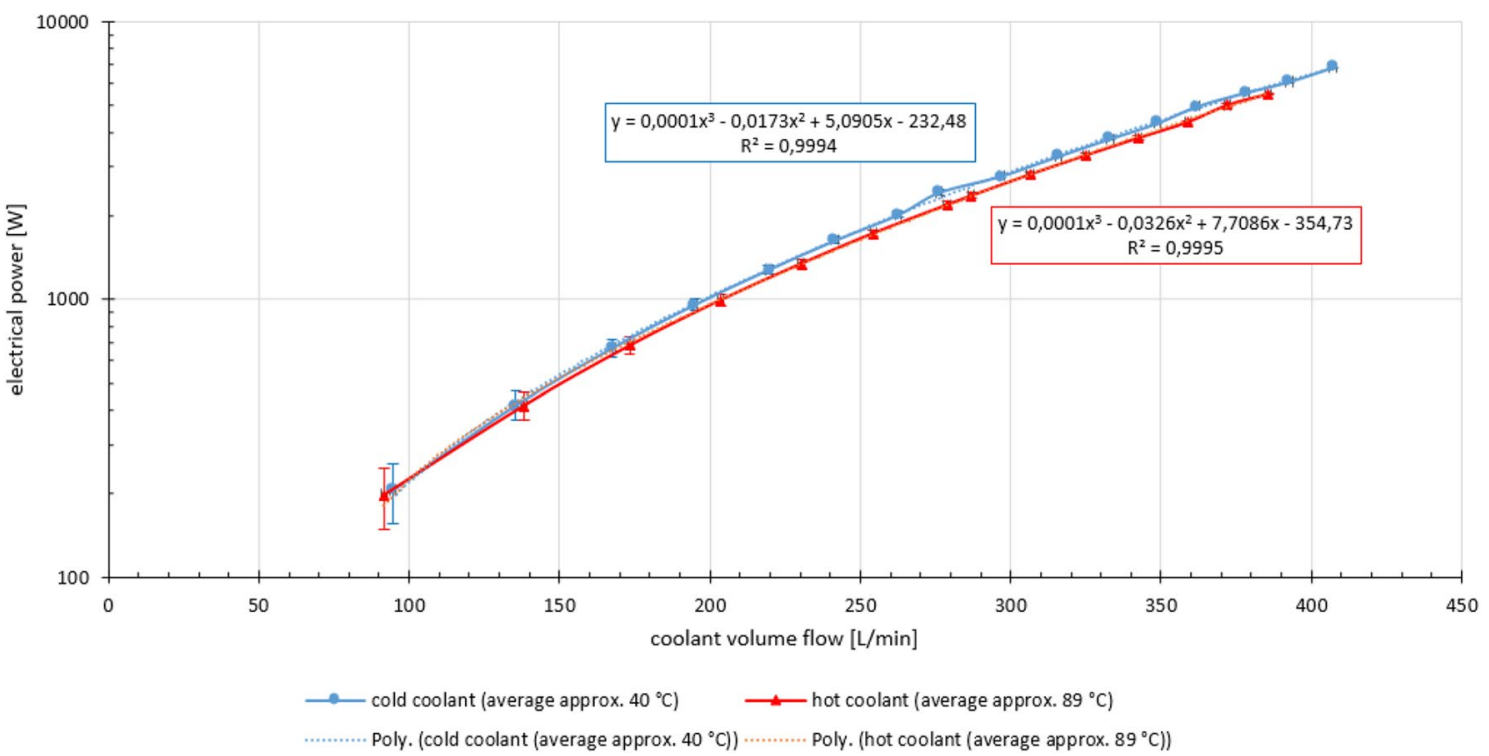

Fig. 8 Long coolant circuit: Electrical power as a function of coolant volume flow for direct drive and different coolant temperatures 
minute and $390 \mathrm{~L}$ per minute. The analysis shows, that for hot coolant in average $5.5 \%$ less electrical power is needed to achieve the same amount of coolant flow.

\subsection{Comparison of the three different drive variants}

For all three different drive alternatives the need of electrical power as a function of volume flow was measured and the results are shown in Fig. 9. Polynomials were created for all three drive variants and these were examined for the deviation in the need of electrical power between $90 \mathrm{~L}$ per minute and $370 \mathrm{~L}$ per minute. The results show that the variant with belt drive and fully engaged viscous clutch needs the most electrical energy in average. The second best drive variant is the direct drive of the coolant pump, which requires approximately $0.4 \%$ less electrical power on average to provide the same coolant volume flow. The drive variant with belt drive and rigid coupling to the drive shaft needs $1.4 \%$ less electrical power and is therefore the best option of all three investigated variants.

A detailed look at the measurement results shows, that there are several intersection points within the diagram. This leads to the fact, that there are values of the coolant volume flow where a different variant is the most efficient. In order to explain this more detailed, the diagram is enlarged to a coolant volume flow range from $110 \mathrm{~L} \mathrm{per}$ minute to $120 \mathrm{~L}$ per minute. This coolant volume flow is necessary for the diesel engine of a long-haul truck on a flat road with 40 tonnes overall weight and a speed of $85 \mathrm{~km}$ per hour.

Figure 10 illustrates the required electrical power in this coolant volume flow range. It can be seen that in the range of $110 \mathrm{~L}$ per minute to $120 \mathrm{~L}$ per minute the most electrical power is required for the direct drive variant. At $115 \mathrm{~L}$ per minute the option "belt drive with fully engaged viscous clutch" requires about $2 \%$ less electrical energy and the variant "belt drive without viscous clutch" (rigid connection) needs approximately 3.3\% less electrical energy than the direct drive version. Therefore, at this value of coolant volume flow, another ranking order of variants result. Although, the option "belt drive without viscous clutch" is the efficiency winner.

Due to the usage of the belt drive a transmission ratio of $i=3.16$ can be achieved. The result of this measure is that the $48 \mathrm{~V}$ motor is operated at higher average efficiency and electrical energy can be saved. However, the belt drive itself causes losses (see Sect. 3) that partially compensate the energy savings due to the higher efficiency of the $48 \mathrm{~V}$ motor.

The analysis of the measurement results shows, that the difference between the three drive variants is not really overwhelming. As mentioned before, the variant "belt drive without viscous clutch" needs approximately $1.4 \%$ less electrical energy within the coolant volume flow from $90 \mathrm{~L}$ per minute to $370 \mathrm{~L}$ per minute. This minor difference doesn't justify the higher technical effort (belt, deflection pulleys, tensioner pulley, conspicuous holding on the diesel engine and added weight). The belt also has structural and acoustic disadvantages and therefore doesn't legitimate the low savings in electrical energy consumption. Furthermore, the belt has to be changed several times within the vehicle life span. From a technical point of view the option "direct drive" is the best overall solution, even if the efficiency of the utilized $48 \mathrm{~V}$ motor doesn't reach the maximum value for this type of drive due to the low speed.

To be able to deliver the mandatory coolant volume flows, which are calculated by the ECU, the $48 \mathrm{~V}$ motor has to fulfill the coolant pump requirements regarding
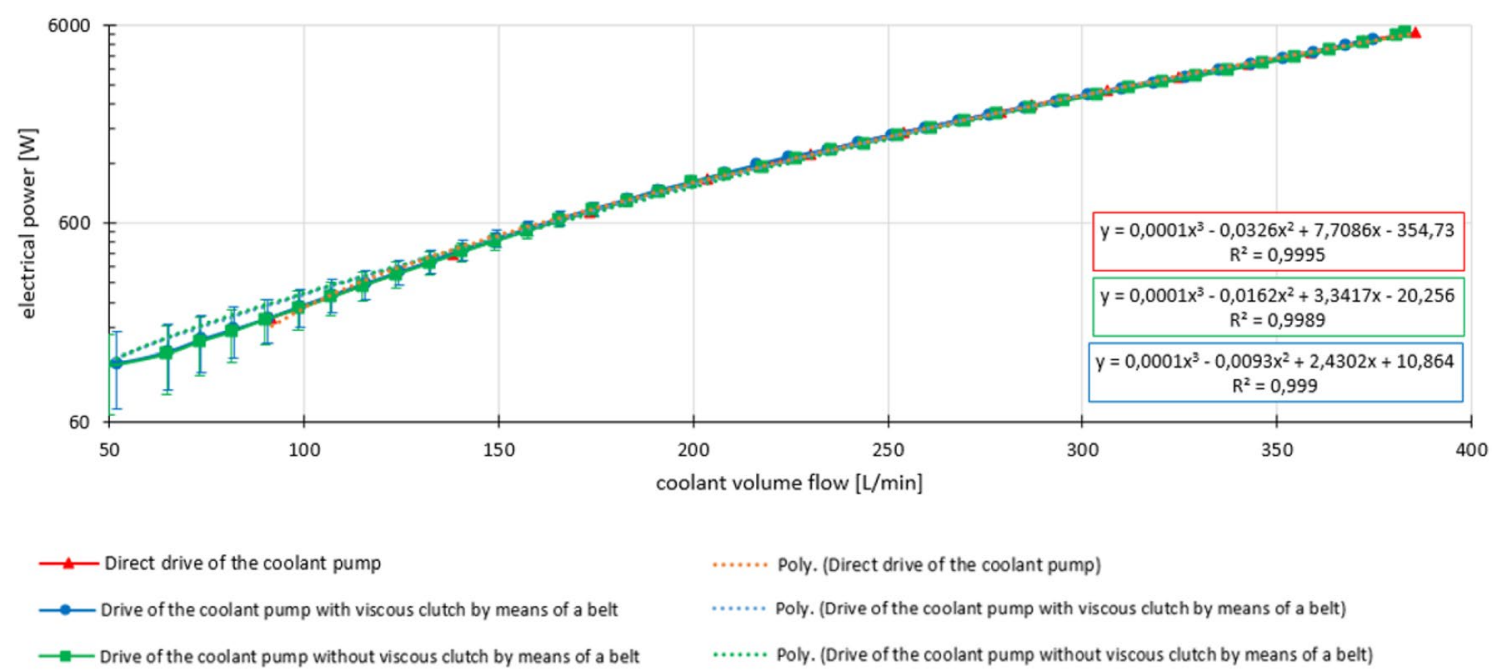

Fig. 9 Comparison of the three different drive variants: Electrical power as a function of coolant volume flow 


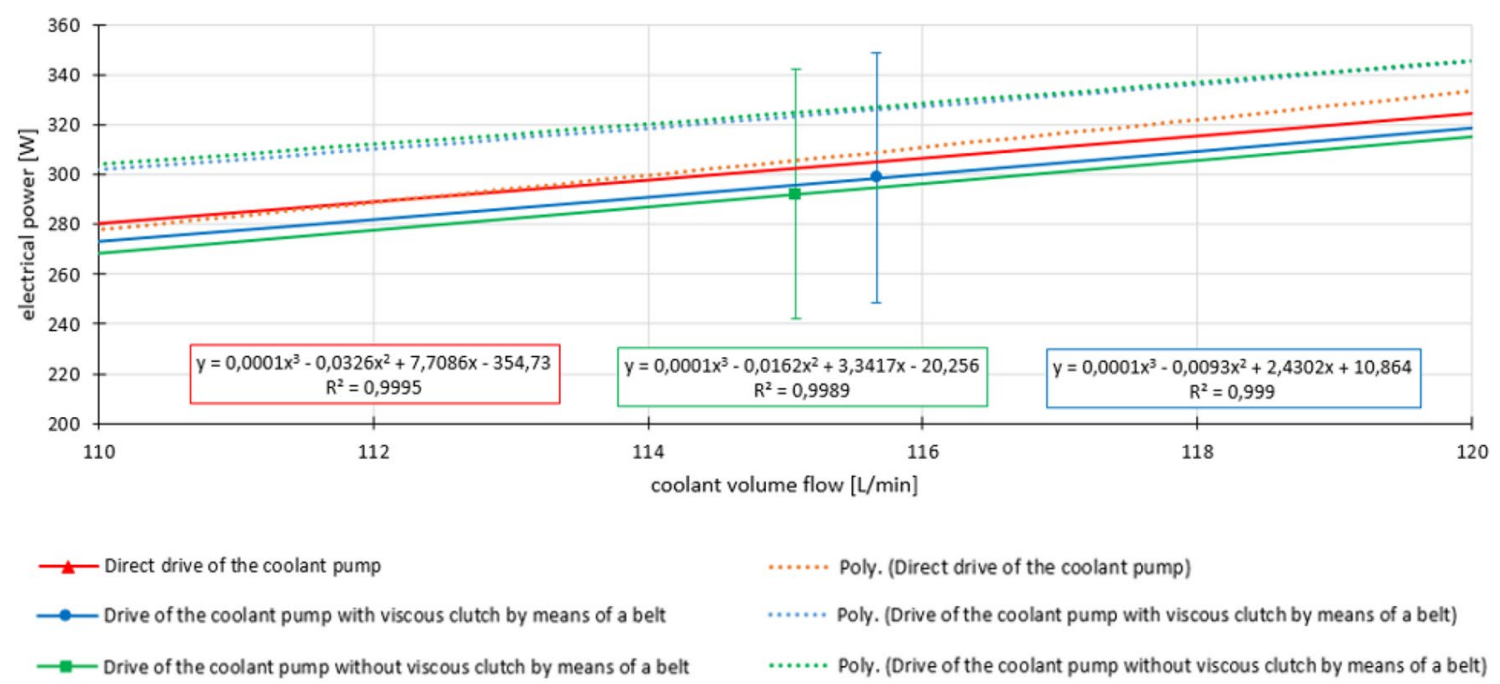

Fig. 10 Comparison of the three different drive variants: Electrical power as a function of coolant volume flow (detailed view)

speed and torque. It's recommended to adjust these coolant pump demands with the 48 motor to achieve a high overall efficiency. If this research project turns into a serial development, it's mandatory to develop a suitable and more compact $48 \mathrm{~V}$ motor to propel the coolant pump.

\subsection{Potential for savings in the engine map}

Standard coolant pumps are driven by a belt drive, which in turn is supplied with mechanical energy from the combustion engine. This increases fuel consumption and reduces the useable mechanical power of the combustion engine. Therefore, the fuel savings potential resulting from the elimination of the mechanically driven coolant pump with viscous clutch and the belt drive were evaluated over the entire engine map.
As already mentioned in Sect. 4, the engine control unit (ECU) calculates the required coolant volume flow depending on several influencing factors. The results of these calculations were utilized as set points for both the electrified coolant pump and the belt driven coolant pump. The measurements were conducted at the engine test bench with the direct drive and the results are shown in Fig. 11.

The savings in fuel consumption, which are presented in Fig. 11, were calculated from the difference between the particular absolute consumption. Figure 11 also illustrates that the highest saving potentials from the electrification of the coolant pump are located in the lower speed and lower load range. The saving potential is correspondingly large due to the elimination of the mechanical coolant pump, the belt drive and the load

\begin{tabular}{|c|c|c|c|c|c|c|c|c|c|c|c|c|}
\hline \multirow{3}{*}{$\begin{array}{c}\text { Maximum fuel savings } \\
\text { [\%] } \\
\text { Torque }[\mathrm{Nm}]\end{array}$} & \multicolumn{12}{|c|}{ Speed [rpm] } \\
\hline & \multirow{2}{*}{800} & \multirow{2}{*}{900} & \multirow{2}{*}{1000} & \multirow{2}{*}{1100} & \multirow{2}{*}{1200} & \multirow{2}{*}{1300} & \multirow{2}{*}{1400} & \multirow{2}{*}{1500} & \multirow{2}{*}{1600} & \multirow{2}{*}{1700} & \multirow{2}{*}{1800} & \multirow{2}{*}{1900} \\
\hline & & & & & & & & & & & & \\
\hline 0 & $-5,59$ & $-7,79$ & $-4,21$ & $-3,77$ & $-4,33$ & $-4,34$ & $-3,44$ & $-3,45$ & $-3,82$ & $-3,21$ & $-4,09$ & $-2,54$ \\
\hline 200 & $-10,64$ & $-1,76$ & $-1,96$ & $-1,73$ & $-2,03$ & $-2,25$ & $-2,15$ & $-2,12$ & $-2,57$ & $-2,24$ & $-0,95$ & $-1,45$ \\
\hline 400 & $-9,01$ & $-1,43$ & $-1,33$ & $-1,14$ & $-1,55$ & $-1,42$ & $-1,60$ & $-1,58$ & $-1,83$ & $-1,63$ & $-2,05$ & $-2,02$ \\
\hline 600 & $-6,91$ & $-0,93$ & $-0,84$ & $-0,72$ & $-1,42$ & $-1,01$ & $-0,89$ & $-1,48$ & $-0,24$ & $-0,48$ & $-0,80$ & $-1,67$ \\
\hline 800 & $-1,85$ & $-0,88$ & $-0,70$ & $-0,63$ & $-0,51$ & $-0,75$ & $-0,79$ & $-0,91$ & $-1,06$ & $-0,95$ & $-1,00$ & $-1,14$ \\
\hline 1000 & $-0,81$ & $-0,70$ & $-0,56$ & $-0,47$ & $-0,38$ & $-0,58$ & $-0,65$ & $-0,81$ & $-0,96$ & $-0,87$ & $-0,89$ & $-1,05$ \\
\hline 1200 & $-1,32$ & $-0,63$ & $-0,43$ & $-0,39$ & $-0,34$ & $-0,41$ & $-0,58$ & $-0,68$ & $-0,91$ & $-0,89$ & $-0,78$ & $-0,82$ \\
\hline 1400 & $-0,84$ & $-0,71$ & $-0,33$ & $-0,30$ & $-0,26$ & $-0,43$ & $-0,45$ & $-0,66$ & $-0,79$ & $-0,83$ & $-0,83$ & $-0,84$ \\
\hline 1600 & $-0,73$ & $-0,70$ & $-0,31$ & $-0,28$ & $-0,34$ & $-0,40$ & $-0,49$ & $-0,73$ & $-0,84$ & $-0,77$ & $-0,92$ & $-1,01$ \\
\hline 1800 & $-0,71$ & $-0,62$ & $-0,32$ & $-0,25$ & $-0,27$ & $-0,32$ & $-0,42$ & $-0,63$ & $-0,84$ & $-0,84$ & $-1,03$ & - \\
\hline 2000 & - & $-0,59$ & $-0,35$ & $-0,24$ & $-0,27$ & $-0,38$ & $-0,46$ & $-0,69$ & $-0,84$ & $-0,82$ & $-0,94$ & - \\
\hline 2200 & - & $-0,53$ & $-0,28$ & $-0,22$ & $-0,28$ & $-0,43$ & $-0,55$ & $-0,84$ & $-0,94$ & - & - & - \\
\hline 2400 & - & - & $-0,26$ & $-0,24$ & $-0,27$ & $-0,51$ & $-0,64$ & - & - & - & - & - \\
\hline 2600 & - & - & - & - & $-0,32$ & $-0,49$ & - & - & - & - & - & - \\
\hline
\end{tabular}

Fig. 11 Maximum savings in fuel consumption due to an electrically driven coolant pump 
removal of the diesel engine at these operating points. The average measured values shown in Fig. 11 is $-1.3 \%$.

The maximum fuel saving potentials shown in Fig. 11 can be achieved if the $48 \mathrm{~V}$ engine for driving the coolant pump is operated with recuperated energy exclusively. If the lithium-ion battery reaches the lower SOC limit and it is necessary to supply the $48 \mathrm{~V}$ engine directly with electrical energy from the $48 \mathrm{~V}$ generator in fired operation points, these fuel saving potentials cannot be achieved due to the long efficiency chain (diesel engine-48V motor/generator-power electronics-wires-power electronics-48V motor to propel the coolant pump).

In order to investigate these operating phases 144 MATLAB $^{\otimes} /$ Simulink $^{\circledR}$-simulations were conducted and the results are shown in Fig. 12. There are 26 operating points (highlighted in orange) in the engine map, where fuel consumption is increased, if the electrical energy for the 48V-motor of the coolant pump is delivered directly from the 48V-MGU in fired operation points. The average increase in fuel consumption of these 26 operating points is $0.29 \%$. Therefore, these operating phases must be avoided by using intelligent operating strategies of the $48 \mathrm{~V}$ mild hybrid system. The development of these operating strategies is part of an ongoing research project and the results will be published at a later date.
For the assessment of the fuel saving potential in real driving cycles MATLAB ${ }^{\circledast} /$ Simulink $^{\circledR}$-simulations were conducted. For these simulations three MAN-internal driving cycles were used, which are briefly presented in Table 7.

The simulation results listed in Table 7 show fuel savings between 0.71 and $0.94 \%$. It is noticeable that fuel savings due to the use of the electrified coolant pump decrease with increasing average diesel engine power. This is caused by an increasing efficiency of the diesel engine at higher engine loads and therefore the difference between a mechanically driven coolant pump and an electrified coolant pump becomes smaller.

Table 8 provides an overview of the energy consumption of the electrical coolant pump in the three different driving cycles. The results of the MATLAB ${ }^{\circledast} /$ Simulink $^{\circledR}$ simulations show that the energy consumption of the electrical coolant pump is increasing with higher average load of the diesel engine. All values in Table 8 include the cable losses and the losses in the power electronics of the 48V-motor, which drives the coolant pump. The simulations were conducted for a long-haul truck without retarder, because a different breaking system (no further details are mentioned in this paper) was used, which has a lower heat input into the cooling system. Therefore, the values shown in Table 8 cover all operating states $\left(90^{\circ} \mathrm{C}\right.$ coolant temperature) of the vehicle.

\begin{tabular}{|c|c|c|c|c|c|c|c|c|c|c|c|c|}
\hline \multirow{3}{*}{$\begin{array}{c}\begin{array}{c}\text { Fuel consumption } \\
\text { difference [\%] }\end{array} \\
\text { Torque }[\mathrm{Nm}]\end{array}$} & \multicolumn{12}{|c|}{ Speed [rpm] } \\
\hline & \multirow{2}{*}{800} & \multirow{2}{*}{900} & \multirow{2}{*}{1000} & \multirow{2}{*}{1100} & \multirow{2}{*}{1200} & \multirow{2}{*}{1300} & \multirow{2}{*}{1400} & \multirow{2}{*}{1500} & \multirow{2}{*}{1600} & \multirow{2}{*}{1700} & \multirow{2}{*}{1800} & \multirow{2}{*}{1900} \\
\hline & & & & & & & & & & & & \\
\hline 0 & $-1,53$ & 3,13 & $-2,02$ & $-1,74$ & $-2,34$ & $-2,37$ & $-1,58$ & $-1,19$ & $-1,11$ & $-0,49$ & $-1,18$ & 0,43 \\
\hline 200 & $-9,66$ & $-0,76$ & $-0,95$ & $-0,80$ & $-1,01$ & $-1,27$ & $-1,21$ & $-0,93$ & $-1,10$ & $-0,73$ & 0,69 & 0,49 \\
\hline 400 & $-6,57$ & $-0,77$ & $-0,69$ & $-0,54$ & $-0,88$ & $-0,75$ & $-0,95$ & $-0,78$ & $-0,78$ & $-0,58$ & $-0,90$ & $-0,80$ \\
\hline 600 & $-4,76$ & $-0,41$ & $-0,37$ & $-0,24$ & $-0,92$ & $-0,53$ & $-0,42$ & $-0,92$ & 0,49 & 0,32 & 0,16 & $-0,55$ \\
\hline 800 & $-0,03$ & $-0,47$ & $-0,34$ & $-0,25$ & $-0,12$ & $-0,36$ & $-0,41$ & $-0,45$ & $-0,44$ & $-0,31$ & $-0,29$ & $-0,34$ \\
\hline 1000 & 0,72 & $-0,32$ & $-0,24$ & $-0,15$ & $-0,06$ & $-0,27$ & $-0,34$ & $-0,42$ & $-0,45$ & $-0,34$ & $-0,27$ & $-0,33$ \\
\hline 1200 & $-0,05$ & $-0,23$ & $-0,10$ & $-0,09$ & $-0,06$ & $-0,14$ & $-0,29$ & $-0,32$ & $-0,46$ & $-0,41$ & $-0,24$ & $-0,22$ \\
\hline 1400 & 0,17 & 0,11 & $-0,01$ & 0,01 & 0,02 & $-0,16$ & $-0,17$ & $-0,31$ & $-0,36$ & $-0,32$ & $-0,18$ & $-0,14$ \\
\hline 1600 & 0,22 & 0,13 & 0,00 & 0,01 & $-0,06$ & $-0,12$ & $-0,20$ & $-0,36$ & $-0,36$ & $-0,19$ & $-0,19$ & $-1,01$ \\
\hline 1800 & $-0,71$ & 0,15 & $-0,01$ & 0,03 & 0,00 & $-0,03$ & $-0,13$ & $-0,23$ & $-0,33$ & $-0,19$ & $-0,16$ & - \\
\hline 2000 & - & 0,13 & $-0,05$ & 0,03 & 0,03 & $-0,08$ & $-0,13$ & $-0,28$ & $-0,21$ & $-0,82$ & $-0,94$ & - \\
\hline 2200 & - & $-0,53$ & 0,02 & 0,03 & 0,01 & $-0,09$ & $-0,17$ & $-0,84$ & $-0,94$ & - & - & - \\
\hline 2400 & - & - & $-0,26$ & $-0,24$ & 0,05 & $-0,15$ & $-0,64$ & - & - & - & - & - \\
\hline 2600 & - & - & - & - & $-0,32$ & $-0,49$ & - & - & - & - & - & - \\
\hline
\end{tabular}

Fig. 12 Change of fuel consumption, if the electrical energy for the 48V-coolant pump is delivered directly from the 48V-MGU

Table 7 Maximum fuel savings in different driving cycles

\begin{tabular}{lcllll}
\hline Driving cycle (-) & $\begin{array}{l}\text { Duration } \\
\text { (seconds) }\end{array}$ & $\begin{array}{l}\text { Cycle profile high- } \\
\text { way/country road [\% } \\
\text { (distance) }\end{array}$ & $\begin{array}{l}\text { Average } \\
\text { engine speed } \\
\text { (rpm) }\end{array}$ & $\begin{array}{l}\text { Average } \\
\text { engine power } \\
(\mathrm{kW})\end{array}$ & $\begin{array}{l}\text { Fuel savings } \\
(\%)\end{array}$ \\
\hline Driving cycle 1 & 766 & $100 / 0$ & 1122 & 63.3 & 0.94 \\
Driving cycle 2 & 1915 & $100 / 0$ & 1158 & 79.9 & 0.77 \\
Driving cycle 3 & 16,117 & $83.59 / 16.41$ & 1167 & 91.6 & 0.71 \\
\hline
\end{tabular}


Table 8 Energy consumption of the electrical coolant pump in different driving cycles

\begin{tabular}{lllr}
\hline Driving cycle (-) & $\begin{array}{l}\text { Average electrical power of } \\
\text { the coolant pump (W) }\end{array}$ & $\begin{array}{l}\text { Maximum electrical power of } \\
\text { the coolant pump (W) }\end{array}$ & $\begin{array}{l}\text { Total } \\
\text { amount of } \\
\text { energy (Wh) }\end{array}$ \\
\hline Driving cycle 1 & 330 & 1158 & 70.2 \\
Driving cycle 2 & 340 & 1158 & 180.8 \\
Driving cycle 3 & 376 & 1774 & 1682.7
\end{tabular}

\section{Additional advantages}

\subsection{Operation of the electric coolant pump with recuperated energy}

During braking and certain overrun phases, the $48 \mathrm{~V}$ motor/generator is able to convert excess mechanical energy into electrical energy. This electrical energy can be used to propel the electric coolant pump directly or can be temporarily stored in the lithium-ion battery for later use. Compared to the conventional coolant pump, this decreases the diesel engine load in the fired phases and results in fuel savings.

\subsection{Use of residual engine heat to heat the driver's cabin:}

After switching off the diesel engine after a longer journey (>20 min), the engine has the full operating temperature of approximately $90^{\circ} \mathrm{C}$. Therefore a lot of heat is stored in the coolant, in the engine oil and in the metallic parts of the engine, which could be used to heat the driver's cabin. For this purpose, an electrical coolant pump is needed. To achieve a defined minimum volume flow (approx. $16 \mathrm{~L} \mathrm{per}$ minute according to [27]) in the cabin heat exchanger, only a very low coolant volume flow has to be realized in the diesel engine itself. At an ambient temperature of $-30^{\circ} \mathrm{C}$ the driver's cabin can be heated for about $1-2 \mathrm{~h}$ with this principle [27]. By using the residual heat of the engine, the parking heater can be activated later if the driver spends the night or takes a longer break in the cabin. This also leads to a further fuel savings potential.

\subsection{Post-run of the electrical coolant pump to protect engine parts}

If an internal combustion engine equipped with a mechanically driven coolant pump is turned off, the coolant volume flow collapses within a few seconds to $0 \mathrm{~L}$ per minute. This can lead to damage of engine components, if the diesel engine has been operated at high load points immediately before the shutdown. In this scenario an electrical coolant pump would have the advantage that a defined coolant volume flow could still be provided for e.g. 1-2 min. The life span of various engine components can be extended in this way. A start-stop system could also be activated more often, because the combustion engine could be switched off immediately, even after high load points.

\subsection{Faster warm-up phase of the diesel engine}

With an electrical coolant pump, very low-in extreme cases even $0 \mathrm{~L}$ per minute-volume flows can be achieved. This is a particular advantage in the warm-up phase of the combustion engine, because the coolant, the engine oil and all engine components heat up more quickly. This leads to a reduction of friction, wear and fuel consumption $[28,29]$. The necessary operating temperatures of the very complex exhaust aftertreatment systems are reached more quickly and therefore emissions can be effectively reduced at an earlier stage [29].

\subsection{Elimination of the belt drive}

As already mentioned in Sect. 3, the losses of the belt drive of the D2676-engine are in the range between 300 and $900 \mathrm{~W}$. If the coolant pump and the air-conditioning compressor are electrified and the $48 \mathrm{~V}$ generator uses a direct mechanical connection to the diesel engine (e.g. power take-off), then the belt drive (8PK belt) can be completely eliminated. In this case the above-mentioned losses can be avoided. There are also advantages in terms of acoustics and vehicle maintenance, because the belt would otherwise have to be replaced several times during the vehicle life span.

\subsection{Additional advantages of an electrical coolant pump}

Due to the conceptual design, the coolant pump with viscous clutch reacts relatively slowly to changes in the degree of engagement and is dependent on the temperature of the viscous oil (affected by ambient temperature and cooling air mass flow). By comparison, the electrical coolant pump can be controlled very quickly and is able 
to react to changes in the speed setting within fractions of a second. As mentioned in Sect. 4, the required coolant volume flow is calculated in the engine control unit (ECU). The electrical coolant pump can provide the calculated volume flow much more accurately than the mechanically driven coolant pump with viscous clutch.

When using a mechanical coolant pump driven via a belt drive, the position of the coolant pump pulley is fixed to the same plane as the belt drive. The electrified coolant pump, on the other hand, can be mounted anywhere on the combustion engine, giving engine designers more freedom in arranging the auxiliary units.

In addition, the fact that the speed of the coolant pump is independent of the internal combustion engine's speed enables this cooling concept to be utilized in hybrid electric vehicles, which combine electrical propulsion systems with internal combustion engines. In this case, a coolant volume flow can be provided despite the internal combustion engine is turned off.

\section{Conclusion}

In this paper, the electrification of the coolant pump on a commercial vehicle diesel engine was discussed. For this purpose, three different drive concepts were realized and tested on the engine test bench. To propel the coolant pump, a $48 \mathrm{~V}$ motor was utilized, which is already in series production in the passenger car sector. The best measurement results were achieved with the drive variant "belt drive without viscous clutch". Nevertheless, the difference to the much simpler variant "direct drive" with only $1.35 \%$ in savings in electrical energy demand from the coolant pump does not justify the much higher effort (belt, belt tensioner, more complex mounting and therefore additional weight).

The measurement results on the engine map show, that the highest savings potentials due to electrification of the coolant pump are located in the lower speed and lower load range. In the entire engine map with its 144 measuring points, an average saving in fuel consumption of $1.3 \%$ was detected, if the electrical coolant pump can exclusively be operated with recuperated energy. Three MAN-internal driving cycles were examined and the results show an average reduction in fuel consumption of $0.71-0.94 \%$. The average electrical power of the $48 \mathrm{~V}$-coolant pump in these three driving cycles were within a range of $330 \mathrm{~W}$ and $376 \mathrm{~W}$.

If the lithium-ion battery is empty (low SOC-level) and it is necessary to supply the electrical coolant pump directly with electrical energy from the $48 \mathrm{~V}$-generator in fired operation points, there are 26 operating points in the engine map, where the fuel consumption is higher compared to the mechanically driven coolant pump. In average the fuel consumption is increased by $0.29 \%$ in these operating points. Therefore, it's vital to operate the electrical coolant pump with recuperated electrical energy as often as possible.

The life span of this $48 \mathrm{~V}$ motor is specified by the manufacturer as $300,000 \mathrm{~km}$ or 8000 operating hours. This is sufficient for conducting the tests on the engine test bench, but not enough for the use in commercial vehicles, where up to 30,000 operating hours or $1,500,000 \mathrm{~km}$ are expected.

All three drive variants with this $48 \mathrm{~V}$ engine are suitable for the engine test bench, but not for the use in an actual commercial vehicle. This would require the utilization of a more compact $48 \mathrm{~V}$ motor with the same performance, but less axial length. A concept for this has already been developed with a German company, which is specialized in manufacturing compact electric motors. Test bench experiments with this new 48V motor are planned for 2021.

The utilization of an electrical coolant pump in commercial vehicles not only results in advantages in terms of fuel consumption, but also in other additional features, such as the use of residual engine heat to warm the driver's cabin, the post-run of the coolant pump to protect various engine components, the shorter warm-up time of the diesel engine and the elimination of the belt drive. All these advantages justify the use of an electrified coolant pump based on $48 \mathrm{~V}$ in commercial vehicles, even though it will be slightly more expensive to manufacture than the current mechanical coolant pump with adjustable viscous clutch.

\section{Compliance with ethical standards}

Conflict of interest The author states that there is no conflict of interest.

Open Access This article is licensed under a Creative Commons Attribution 4.0 International License, which permits use, sharing, adaptation, distribution and reproduction in any medium or format, as long as you give appropriate credit to the original author(s) and the source, provide a link to the Creative Commons licence, and indicate if changes were made. The images or other third party material in this article are included in the article's Creative Commons licence, unless indicated otherwise in a credit line to the material. If material is not included in the article's Creative Commons licence and your intended use is not permitted by statutory regulation or exceeds the permitted use, you will need to obtain permission directly from the copyright holder. To view a copy of this licence, visit http://creativecommons .org/licenses/by/4.0/. 


\section{References}

1. Official Journal of the European Union (2019) REGULATION (EU) 2019/1242 OF THE EUROPEAN PARLIAMENT AND OF THE COUNCIL of 20 June 2019 setting CO2 emission performance standards for new heavy-duty vehicles and amending Regulations (EC) No 595/2009 and (EU) 2018/956 of the European Parliament and of the Council and Council Directive 96/53/EC. https://eurlex.europa.eu/legal-content/EN/TXT/PDF/?uri=CELEX:32019 R1242\&from $=E N$. Accessed 022020

2. Fritsch KM, Weber S, Krappel M, Elsaesser A (2015) Electrical 48-V main coolant pump to reduce $\mathrm{CO} 2$ emissions. Auto Tech Rev. https://doi.org/10.1007/s38313-015-0065-z

3. Krappel M, Heidecker C, Streng S, Elsaesser A (2015) Electrical $48 \mathrm{~V}$ coolant pump for highest thermal management requirements. Springer Fachmedien Wiesbaden. https://doi. org/10.1007/978-3-658-08844-6_84

4. Schoeffmann W, Sorger $H$, Weissbaeck M (2017) Efficient and cost-optimised powertrain for 48-V systems. Springer Fachmedien Wiesbaden. https://doi.org/10.1007/s38313-017-0062-5

5. Schoeffmann W, Sorger H, Ennemoser A, Priestner C (2017) The impact of $48 \mathrm{~V}$ to friction and efficiency optimization of the base engine-approach for quantification in future driving cycles. Springer Fachmedien Wiesbaden. https://www.springerprofess ional.de/der-einfluss-von-48-v-auf-grundmotorreibungsun d-effizienzoptimie/15191162? searchResult $=31.48 \mathrm{~V} \% 20 \mathrm{coo}$ lant\%20pump\&searchBackButton=true. Accessed 062020

6. Mitterecker $\mathrm{H}$, Wieser $M$, Weißbaeck M, Wancura $H$ (2018) The diesel engine as an important component for $\mathrm{CO} 2$ fleet target achievement. Springer Fachmedien Wiesbaden. https://doi. org/10.1007/s38313-018-0043-3

7. Treutler J, Toepfer T, Dingel O (2017) Combination of ORC system and electrified auxiliaries on a long haul truck equipped with 48-Volt board net. Energy Procedia. https://doi.org/10.1016/j. egypro.2017.09.135

8. Granitz C, Ratzinger J, Eichlseder H, Surace A (2019) Application of electrically driven coolant pumps on a heavy-duty diesel engine. SAE International. https://www.sae.org/publications/ technical-papers/content/2019-01-0074/. Accessed 122020

9. van Basshuysen R, Schaefer F (2015) Handbuch Verbrennungsmotor, 7th edn. Springer Vieweg, Wiesbaden

10. MAN Department GPGI (2017) PAM - die neuen MAN Motoren Truck Modelljahr 2017 (MAN-internal file). MAN Truck \& Bus SE, Munich

11. Schydlo A, Döbereiner R (2016) Holistische Regelungsstrategie für Kühlungskomponenten. MTZ 07-08/2016

12. Mollenhauer K, Tschöke H (2018) Handbuch Dieselmotoren. Springer Fachmedien, Berlin
13. Engineering ToolBox (2003) Values interpolated. https://www. engineeringtoolbox.com/ethylene-glycol-d_146.html. Accessed 062020

14. MAN Department GPTS (2019) PAM Motoren Truck Euro 6d (MAN-internal file). MAN Truck \& Bus SE, Munich

15. Stiel W (1918) Theorie des Riementriebs. Julius Springer, Berlin

16. Ritter J (2014) MAN-interne Simulationsergebnisse zu Verlusten bei Riementrieben (MAN-internal file). MAN Truck \& Bus SE, Nuremberg

17. Tschoeke H, Gutzmer P, Pfund T (2019) Elektrifizierung des Antriebsstrangs. Springer Vieweg, Wiesbaden

18. KTR Kupplungstechnik GmbH (2016) Antriebstechnik2016.pdf. www.ktr.com. Accessed 062020

19. Bernath $M$ (2017) Geregelte-KMP-Viscokupplungsverluste.pptx (MAN-internal file). MAN Truck \& Bus SE, EPCN, Munich

20. Endress+Hauser (2007) Technische Information - Proline Promass 80/83 F M - Coriolis-Massedurchfluss-Messsystem. Technical Information of the manufacturer

21. Norm DIN EN 60751:2009-05 (2009) Standardization

22. HEIDEN power GmbH (2017) Dokumentation zum PSI 9080-340 3U. File 06230350_TFT_DE.pdf. included in delivery

23. HBM Hottinger Baldwin Messtechnik GmbH (2020) Digitaler Drehmomentaufnehmer T40B. https://www.hbm.com/de/. Accessed 042020

24. HBM Hottinger Baldwin Messtechnik GmbH (2020) Drehmomentaufnehmer-T40.pdf. File of manufacturer

25. DR. JOHANNES HEIDENHAIN GmbH (2020) https://www.heide nhain.de/fileadmin/pdb/media/img/349529-1K_Drehgeber_ de.pdf. Accessed 042020

26. AVL Pierburg Instruments Flow Technology GmbH (2005) Betriebsanleitung PLU 116H.pdf. File of manufacturer

27. Schydlo A (2016) Nachheizen der Fahrerkabine - Simulationsergebnisse (MAN-internal file). MAN Truck \& Bus SE, Munich

28. Castiglione T, Perrone D, Morrone P, Algieri A, Bova S (2019) Thermal management strategies for $\mathrm{CO} 2$ reduction in powertrain systems. https://aip.scitation.org/doi/pdf/10.1063/1.51387 73?download=true. Accessed 062020

29. Pierburg Pump Technology GmbH (2020) Elektrische Kuehlmittelpumpen. https://www.rheinmetall-automotive.com/filea $\mathrm{dmin} / \mathrm{media} / \mathrm{kspg} /$ Broschueren/Poduktbroschueren/Pierb urg_Pump_Technology/Wasserumwaelz-_und_Kuehlmitte Ipumpen/ppt_elek_kuehlmittelp_d.pdf. Accessed 062020

Publisher's Note Springer Nature remains neutral with regard to jurisdictional claims in published maps and institutional affiliations. 